\title{
Evaluation of Primordial Radionuclides in Ocimum gratissimum and health Risk to the Consumers at Ewekoro Southwest of Nigeria
}

\author{
${ }^{* 1}$ SOWOLE, O; ${ }^{1}$ OLANIYI, OE; ${ }^{2}$ AMODU, FR \\ ${ }^{*}$ Department of Physics, College of Science and Information Technology, Tai Solarin University of Education, P.M.B. 2118, Ijebu-Ode, \\ Ogun State, Nigeria \\ ${ }^{2}$ Department of Science Laboratory Technology, Federal Polytechnic, Ede, Osun State, Nigeria \\ *Correspondence AuthorEmail: sowoleo@tasued.edu.ng, segunsowole@yahoo.com \\ Tel: +2349099204812, +2348023531317
}

\begin{abstract}
Primordial radionuclides are transported in to the plants through the leaves and roots. Medicinal plants are widely used in Africa for prevention and treatment of diseases. Ocimum Gratissimum is medicinal plant that is so used in southwest of Nigeria due to its multifunctional traditional medicinal health uses and as spice in cooking. The research is to determine the radiological health risk of these primordial radionuclides to the consumers of Ocimum Gratissimum in the study area. Fresh leaves of the medicinal plant were plucked from ten (10) different locations at Ewekoro where mining of limestone had been taking place in Ogun State, southwest of Nigeria, been the part of the plant that was commonly used. The concentrations of ${ }^{40} \mathrm{~K},{ }^{238} \mathrm{U}$ and ${ }^{232} \mathrm{Th}$ in the fresh leaves were determined using gamma spectrometry method, and average annual committed effective dose to the adult consumers was determined. No artificial radionuclide was detected. The highest annual committed effective doses of ${ }^{40} \mathrm{~K},{ }^{238} \mathrm{U}$ and ${ }^{232} \mathrm{Th}$ to the consumers of Ocimum Gratissimum were obtained to be $0.00133 \mathrm{mSvy}^{-1}, 0.00147 \mathrm{mSvy}^{-1}$ and $0.00336 \mathrm{mSvy}^{-1}$ respectively. The highest excess lifetime cancer risk of ${ }^{40} \mathrm{~K},{ }^{238} \mathrm{U}$ and ${ }^{232} \mathrm{Th}$ to the consumers were calculated to be $0.0211 \times 10^{-3}, 0.0136 \times 10^{-3}$ and $0.1434 \times 10^{-3}$ respectively. The average annual committed effective dose and average excess lifetime cancer risk of the radionuclides to the consumers were calculated to be $0.0109 \mathrm{mSvy}^{-1}$ and $0.0379 \times 10^{-3}$ respectively. The values were below the limits of $0.3 \mathrm{mSvy}^{-1}$ and $0.29 \times 10^{-3}$ respectively, recommended globally. The consumers of the medicinal plant do not have significant radiological health risk. Furthermore, the results obtained can serve as reference data for future studies in the study area and its environs.
\end{abstract}

DOI: https://dx.doi.org/10.4314/jasem.v24i2.24

Copyright: Copyright $\left({ }^{\circ} 2020\right.$ Sowole et al. This is an open access article distributed under the Creative Commons Attribution License (CCL), which permits unrestricted use, distribution, and reproduction in any medium, provided the original work is properly cited.

Dates: Received: 16 November 2019; Revised: 11 January 2020; Accepted: 22 February 2020

Keywords: Primordial Radionuclide, Medicinal plant, Dose, Cancer

An emerging problem in many developing countries is industrial pollution that causes contamination of vegetation with heavy metals, pesticides, or radioactivity (Duffy et al., 1999). Some industrial establishments like the phosphate, mining and agricultural activities can also release technologically enhanced naturally occurring radioactive materials into the environment. One type of industrial activities which is also a potential of naturally occurring radionuclide release into the environment is during cement manufacture. The environmental problem of the cement industry is the release of cement dust. Cement dust has been identified as consisting significant amount of primordial radionuclides of ${ }^{238} \mathrm{U},{ }^{232} \mathrm{Th}$ and ${ }^{40} \mathrm{~K}$ (Mujahid et al., 2007). Cement dust spreads along large areas through wind, rain and others are accumulated in and on soils, plants and animals, and can affect human health adversely (Bayhan and Özbay , 2006; Dermi, 2005). Sowole
(2014) assessment of our environment radiologically is so important in order to ascertain safety of man due to exposure to radionuclides. Ingestion and inhalation are the main pathways through which natural radinuclides enter into the human body, and it can be so dangerous for human health. According to Tawalbeh et al. (2012) ingested radionuclides could be concentrated in certain parts of the body. For example, chemical uranium toxicity primarily affects the kidney, causing damage to the proximal tubule, while this metal has also been identified as a potential reproductive toxicant (Linares et al., 2005), ${ }^{232} \mathrm{Th}$ causes effect in lungs, liver and skeleton tissues and ${ }^{40} \mathrm{~K}$ in muscles. Depositions of large quantities of these radionuclides in particular organs will affect the health condition of the human such as weakening the immune system, induce various types of diseases, and finally increase in mortality rate (Tawalbeh et al., 2012). The presence of 
radionuclides in plants constitutes a pathway for their transfer to man the consumer.

The use of herbal plants in treatment of diseases has been in existence in Nigeria before the era of colonization when western medicine was introduced. According to Ayitey-Smith (1989), traditional medicine which involves the use of herbal plants evolved from environmental resources, which the people of a community adapted in desperation for survival from disease. On the African continent, traditional medical practices date as far back as 4000 years. It was the sole medical system for health care before the advent of orthodox or modern medicine. According to World Health Organization (2002), up to $80 \%$ of persons living in Africa, use traditional medicines, especially herbal medicine for their primary healthcare needs. Even, in developed countries such as the United States, herbal products have seen an increasing level of use and it is now used by approximately $20 \%$ of the population (Bent, 2008). With this, high level of use of herbal medicines in both developed and developing countries has been noticed. For people in developing countries, high dependence on herbal medicine may be due to the ease of accessibility, affordability, availability and acceptability. With developed countries; however, the drive for the use of herbal medicine may stem from the notion that as plants, herbs are natural hence safer (Ernst, 1998; Tamuno, 2011). According to the International Food Safety Authorities Network (INFOSAN, 2011) and Tettey-Labri et al. (2013), plants used as food commonly have ${ }^{40} \mathrm{~K},{ }^{232} \mathrm{Th}$ and ${ }^{238} \mathrm{U}$ and their progenies. It is expected that similarities would be found in plants used for medicinal purposes since plants are the primary pathway of natural radionuclides entering into the human body through the food chain. In a variety of concentrations, Naturally Occurring Radioactive Materials (NORMs) have always been present in every part of the earth and in the tissue of all living beings. Natural radionuclides such as ${ }^{238} \mathrm{U},{ }^{232} \mathrm{Th}$ and ${ }^{40} \mathrm{~K}$ can be found almost everywhere; in soil, public water supplies, oil and atmosphere thereby subjecting human beings to reasonable exposure (Ali, 2008; Varier, 2009). The role of NORMs in animal and plant metabolism has long been established, but their effect and influence on administration of medicinal plants had received relatively little attention without due regard to possible side effects because they have been perceived to be in smaller quantities meanwhile mankind has continually used traditional herbal medicine from medicinal plants for the treatment of various diseases and ailments (Odugbemi, 2006; Odugbemi and Akinsulire, 2008; Okoli et al., 2007; Oladipo et al., 2012). The plant Ocimum Gratissimum (OG) is one of those plants widely known and used for both medicinal and nutritional purpose. The plant is found throughout the tropics and subtropics and its greatest variability occurs in tropical Africa and India (Aruna and Sivaramakrishina, 1990). It is of the family Labiatae, genus Ocimum and specie Gratissimum. The plant is an erect small plumb with many barnacles usually not more than $1 \mathrm{~m}$ high (Vierra and Simon, 2000). The common names of the plant are Basil fever plant or tea bush and local names among the tribes in Nigeria are: 'Daidoya tagida' (Hausa), 'Nehonwu' (Igbo), 'Tanmotswangiwawagi' (Nupe) and 'Efinrin' (Yoruba). In Nigeria and several other countries, the plant plays important roles in traditional medicine preparations (Gill, 1992); include use in stomach disorder treatment and for treatment of sunstroke, headache and influenza. In the coastal areas of Nigeria, the plant is used in the treatment of epilepsy, high fever, and diarrhea (Effraim et al., 2003).

In Nigeria today, the use of herbal medicines for therapeutic purposes has increased drastically due to the fact that medicinal plants are cheap, readily available and widely distributed. Apart from the high cost of procuring available allopathic medicines for treating even common health disorders, other reasons for this shift are inaccessibility of health institutions in the rural or remote locations in the country and growing awareness of adverse reaction to some allopathic drugs. Besides, Nigeria being in the tropics, has forest that are full of cheap, easily available and sustainable medicinal plants which can be used and have always been used for the treatment of various diseases (Oni et al., 2011). Herbal medicine in Nigeria of today has taken new dimension due to the fact that the traditional practitioners now go into partnership with pharmacologists and pharmacists in the aspect of effective dosage and preservation. It is a known fact that the drugs being used in orthodox medicine are produced from extracts from herbal plants. More so, pharmacists and pharmacologists inquire the knowledge of herbal plants from traditional medicine practitioners. That shows that the use of herbal plants for treatment of diseases has been so effective. This research work determined the concentrations of the primordial radionuclides present in the leaves of Ocimum Gratissimum medicinal plant, annual committed effective doses and excess lifetime cancer risk to the consumers of the leaves or the extracts from the leaves at Ewekoro in Ogun State, being the major part of the plant that is commonly used.

\section{MATERIALS AND METHODS}

The study area: Ewekoro is a Local Government in Ogun State, southwest of Nigeria, of location $6^{\circ} 56^{\prime} \mathrm{N}$ $3^{\circ} 13^{\prime} \mathrm{E}$. It has the population of about 55,156 covering 
the area of $594 \mathrm{~km}^{2}$. The Ewekoro region is underlain by major deposit of limestone which is being mined and used for the production of cement in the town.

Samples collection and preparation: The fresh leaves of Ocimum Gratissimum were plucked from the shrubs from ten (10) locations at Ewekoro, Ogun State in Nigeria. They were kept in different plastic containers and well labeled for easy identification. The samples were thoroughly washed with spring water and rinsed with distilled water in order to prevent contamination of the samples. The leaves were dried for 5 minutes in an oven at $60^{\circ} \mathrm{C}$ to stop enzyme activity (Effraim et al., 2000). They were then air dried at room temperature to a constant weight and milled to powder form after which they were packed $65.0 \mathrm{~g}$ in plastic containers of base diameter $5.0 \mathrm{~cm}$ so as to sit comfortably on the $\mathrm{NaI}(\mathrm{Tl})$ detector used in this work. The samples were all sealed and kept for 28days in order to obtain secular equilibrium between radioactive daughter nuclides and their respective progenies.

Experimental analysis: The method of gamma spectrometry was adopted for the analysis of the samples collected in order to obtain data on ${ }^{40} \mathrm{~K},{ }^{238} \mathrm{U}$ and ${ }^{232} \mathrm{Th}$. The spectrometer used was a Canberra lead shielded $7.6 \mathrm{~cm} \times 7.6 \mathrm{~cm} \mathrm{NaI}(\mathrm{Tl})$ detector coupled to a multichannel analyzer (MCA) through a preamplifier base. The resolution of the detector is about $10 \%$ at $0.662 \mathrm{MeV}$ of ${ }^{137} \mathrm{Cs}$. For the analyses of ${ }^{40} \mathrm{~K},{ }^{238} \mathrm{U}$ and ${ }^{232} \mathrm{Th}$, the photo peak regions of ${ }^{40} \mathrm{~K}(1.46 \mathrm{MeV}),{ }^{214} \mathrm{Bi}$ $(1.76 \mathrm{MeV})$ and ${ }^{208} \mathrm{TI}(2.615 \mathrm{MeV})$ were respectively used. The cylindrical plastic containers holding the samples were put to sit on the high geometry $7.6 \mathrm{~cm} \mathrm{x}$ $7.6 \mathrm{~cm} \mathrm{NaI}$ (TI) detector. High level shielding against the environmental background radiation was achieved by counting in a Canberra $10 \mathrm{~cm}$ thick lead castle. The counting of each sample was done for $10 \mathrm{hrs}$ because of suspected low activities of the radionuclides in the samples.

The areas under the photo-peaks of ${ }^{40} \mathrm{~K},{ }^{238} \mathrm{U}$ and ${ }^{232} \mathrm{Th}$ were computed using the Multichannel Analyzer system. The activity concentrations of the radionuclides were calculated based on the efficiency of the detector and the net count rate under each photopeak over a period of 10 hours using equation 1.0

$$
A=\frac{N\left(E_{\gamma}\right)}{\varepsilon\left(E_{\gamma}\right) I_{\gamma} M t_{c}}
$$

Where: $N\left(E_{\gamma}\right)=$ Net peak area of the radionuclide of interest, $\varepsilon\left(\mathrm{E}_{\gamma}\right)=$ Efficiency of the detector for the $\gamma$ energy of interest, $\mathrm{I}_{\gamma}=$ Intensity per decay for the $\gamma$ - energy of interest, $M=$ Mass of the sample, $t_{c}=$ Total counting time in seconds (36000s).

In addition, the annual committed effective dose (ACED) for ingestion of NORMs in medicinal plants is calculated using the expression (Lordford et al., 2013):

$$
A C E D=C \times D C F \times C R
$$

Where: $\mathrm{C}=$ Concentration of each radionuclide, $\mathrm{DCF}$ $=$ Dose conversion factors for ingestion of the radionuclides and $\mathrm{CR}=$ Consumption rate of intake of NORMs from the medicinal plants.

Excess lifetime cancer risk (ELCR) to man the consumer was determined based on the values of the annual committed effective dose as shown in table 2.0 using equation 3.0

$$
E L C R=A C E D \times L E \times R F
$$

Where LE is life expectancy taken to be 70years and $\mathrm{RF}$ is fatal risk factor per sievert which was 0.05 (ICRP, 2007).

\section{RESULTS AND DISCUSSION}

The leaves of ocimum gratissimum had the highest concentration values of ${ }^{40} \mathrm{~K}$ to be $67.35 \pm 7.02 \mathrm{Bqkg}^{-1}$ which was obtained from $\mathrm{OGS}_{10}$ while the lowest was from $\mathrm{OGS}_{8}$ of value $22.74 \pm 1.58 \mathrm{Bqkg}^{-1} .{ }^{238} \mathrm{U}$ had the highest concentration value of $6.14 \pm 1.27 \mathrm{Bqkg}^{-1}$ from $\mathrm{OGS}_{2}$, while the lowest was $0.97 \pm 0.08 \mathrm{Bqkg}^{-1}$ from $\mathrm{OGS}_{8}$. Concerning ${ }^{232} \mathrm{Th}$, the highest concentration was $12.37 \pm 3.48 \mathrm{Bqkg}^{-1}$ from $\mathrm{OGS}_{2}$ while the lowest was $3.49 \pm 0.45 \mathrm{Bqkg}^{-1}$ from $\mathrm{OGS}_{1}$. The mean values were $45.46 \pm 3.57 \mathrm{Bqkg}^{-1}, 3.75 \pm 0.69 \mathrm{Bqkg}^{-1}$ and 7.86 $\pm 1.72 \mathrm{Bqkg}^{-1}$ for ${ }^{40} \mathrm{~K},{ }^{238} \mathrm{U}$ and ${ }^{232} \mathrm{Th}$ respectively, as shown in table 1 . The values obtained were lower than those obtained in Ghana by Lordford et al. (2013) likewise in India by Chandrashekara and Somashekarappa (2016). No artificial radionuclide was detected in all the samples collected indicating that the mining of limestone activities do not contribute to radiological pollution of the medicinal plant of the study area. The highest ACED as shown in table 2 and figure 1 of ${ }^{40} \mathrm{~K},{ }^{238} \mathrm{U}$ and ${ }^{232} \mathrm{Th}$ to the consumers of Ocimum Gratissimum were obtained to be $0.00133 \mathrm{mSvy}^{-1}, 0.00147 \mathrm{mSvy}^{-1}$ and $0.00336 \mathrm{mSvy}^{-}$ ${ }^{1}$ respectively. The mean values of ACED for ${ }^{40} \mathrm{~K},{ }^{238} \mathrm{U}$ and ${ }^{232} \mathrm{Th}$ were $0.00406 \mathrm{mSvy}^{-1}, 0.00238 \mathrm{mSvy}^{-1}$ and $0.0261 \mathrm{mSvy}^{-1}$ respectively. Average annual committed effective dose of all the radionuclides (AACED) to the consumers was calculated to be $0.0109 \mathrm{mSvy}^{-1}$. 
Table 1. Activity concentrations of natural radionuclides in fresh leaves of Ocimum Gratissimum samples

\begin{tabular}{|c|c|c|c|}
\hline \multirow[t]{2}{*}{ Sample code } & \multicolumn{3}{|c|}{$\begin{array}{l}\text { Activity concentration } \\
\left(\mathrm{Bqkg}^{-1}\right)\end{array}$} \\
\hline & ${ }^{40} \mathrm{~K}$ & ${ }^{238} \mathrm{U}$ & ${ }^{232} \mathrm{Th}$ \\
\hline $\mathrm{OGS}_{1}$ & $56.74 \pm 4.68$ & $4.35 \pm 0.89$ & $10.14 \pm 2.04$ \\
\hline $\mathrm{OGS}_{2}$ & $39.45 \pm 2.76$ & $6.14 \pm 1.27$ & $12.37 \pm 3.48$ \\
\hline $\mathrm{OGS}_{3}$ & $44.92 \pm 3.21$ & $2.47 \pm 0.25$ & $6.92 \pm 1.41$ \\
\hline $\mathrm{OGS}_{4}$ & $36.82 \pm 2.89$ & $3.53 \pm 0.42$ & $8.45 \pm 1.72$ \\
\hline $\mathrm{OGS}_{5}$ & $64.27 \pm 5.36$ & $5.02 \pm 0.96$ & $9.36 \pm 1.84$ \\
\hline $\mathrm{OGS}_{6}$ & $32.85 \pm 2.19$ & $1.83 \pm 0.35$ & $5.82 \pm 0.96$ \\
\hline $\mathrm{OGS}_{7}$ & $51.08 \pm 3.54$ & $4.79 \pm 1.26$ & $3.49 \pm 0.45$ \\
\hline $\mathrm{OGS}_{8}$ & $22.74 \pm 1.58$ & $0.97 \pm 0.08$ & $4.17 \pm 0.82$ \\
\hline $\mathrm{OGS}_{9}$ & $38.36 \pm 2.49$ & $3.15 \pm 0.29$ & $6.04 \pm 1.36$ \\
\hline $\mathrm{OGS}_{10}$ & $67.35 \pm 7.02$ & $5.28 \pm 1.13$ & $11.85 \pm 3.08$ \\
\hline Range & $22.74-67.35$ & $0.97-6.14$ & $3.49-12.37$ \\
\hline Mean & $45.46 \pm 3.57$ & $3.75 \pm 0.69$ & $7.86 \pm 1.72$ \\
\hline
\end{tabular}

Table 2. Determined annual committed effective doses to consumers

\begin{tabular}{|c|c|c|c|c|c|c|}
\hline $\begin{array}{l}\text { Sample } \\
\text { code }\end{array}$ & $\begin{array}{l}{ }^{40} \mathbf{K} \\
\text { ACED } \\
\left(\mathrm{mSvy}^{-1}\right)\end{array}$ & $\begin{array}{l}{ }^{238} U \\
\text { ACED } \\
\left(\mathrm{mSvy}^{-1}\right)\end{array}$ & $\begin{array}{l}{ }^{232} \text { Th } \\
\text { ACED } \\
\left(\mathrm{mSvy}^{-1}\right)\end{array}$ & $\begin{array}{l}{ }^{40} \mathrm{~K} \\
\text { ELCR } \\
\times 10^{-3}\end{array}$ & $\begin{array}{l}{ }^{238} \mathrm{U} \\
\text { ELCR } \\
\times 10^{-3}\end{array}$ & $\begin{array}{l}{ }^{232} \mathrm{Th} \\
\text { ELCR } \\
\times 10^{-3}\end{array}$ \\
\hline $\mathrm{OGS}_{1}$ & 0.00507 & 0.00276 & 0.0336 & 0.0177 & 0.0097 & 0.1175 \\
\hline $\mathrm{OGS}_{2}$ & 0.00352 & 0.00389 & 0.0410 & 0.0123 & 0.0136 & 0.1434 \\
\hline $\mathrm{OGS}_{3}$ & 0.00401 & 0.00157 & 0.0229 & 0.0140 & 0.0055 & 0.0802 \\
\hline $\mathrm{OGS}_{4}$ & 0.00329 & 0.00224 & 0.0280 & 0.0115 & 0.0078 & 0.0980 \\
\hline $\mathrm{OGS}_{5}$ & 0.00574 & 0.00318 & 0.0310 & 0.0201 & 0.0111 & 0.1085 \\
\hline $\mathrm{OGS}_{6}$ & 0.00293 & 0.00116 & 0.0193 & 0.0103 & 0.0041 & 0.0675 \\
\hline $\mathrm{OGS}_{7}$ & 0.00456 & 0.00304 & 0.0116 & 0.0160 & 0.0106 & 0.0405 \\
\hline $\mathrm{OGS}_{8}$ & 0.00203 & 0.00062 & 0.0138 & 0.0071 & 0.0022 & 0.0483 \\
\hline $\mathrm{OGS}_{9}$ & 0.00343 & 0.00200 & 0.0200 & 0.0120 & 0.0070 & 0.0700 \\
\hline $\mathrm{OGS}_{10}$ & 0.00601 & 0.00335 & 0.0393 & 0.0211 & 0.01171 & 0.1374 \\
\hline Mean & 0.00406 & 0.00238 & 0.0261 & 0.0142 & 0.00832 & 0.0911 \\
\hline
\end{tabular}

The values were lower than those obtained by Njinga et al. (2015) and Chandrashekara and Somashekarappa (2016) as stated before.

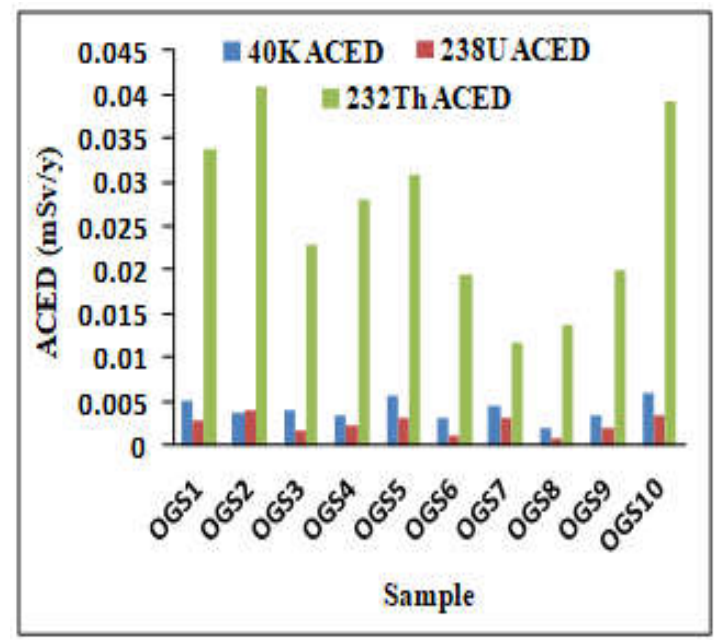

Fig. 1: The values of ACED to the consumers

Furthermore, the values were below the world average recommended limit of $1.0 \mathrm{mSvy}^{-1}$ (ICRP, 2007) for ingestion of natural radionuclides. The lowest excess lifetime cancer risk of ${ }^{40} \mathrm{~K},{ }^{238} \mathrm{U}$ and ${ }^{232} \mathrm{Th}$ to consumers were $0.0071 \times 10^{-3}$ from $\mathrm{OGS}_{8}, 0.0022 \times$
$10^{-3}$ from $\mathrm{OGS}_{8}$ and $0.0405 \times 10^{-3}$ from $\mathrm{OGS}_{7}$ respectively.

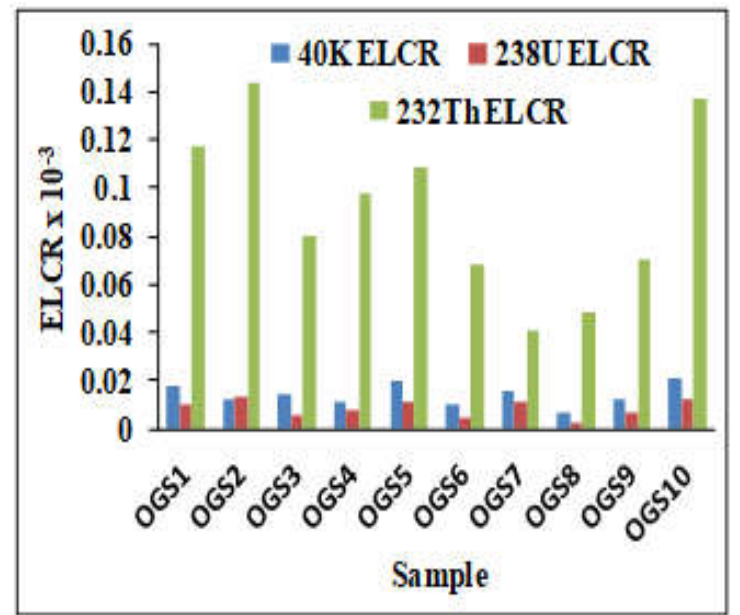

Fig. 2: The values of ELCR to the consumers

The highest excess lifetime cancer risk of ${ }^{40} \mathrm{~K},{ }^{238} \mathrm{U}$ and ${ }^{232} \mathrm{Th}$ to the consumers were calculated to be $0.0211 \mathrm{x}$ $10^{-3}$ with mean value of $0.0142 \times 10^{-3}, 0.0136 \times 10^{-3}$ with mean value of $0.00832 \times 10^{-3}$ and $0.1434 \times 10^{-3}$ with mean value of $0.0911 \times 10^{-3}$ respectively as shown in table 2 . 
The average ELCR for all the radionuclides was $0.0379 \times 10^{-3}$. All the values were below the limit of $0.29 \times 10^{-3}$ (UNSCEAR, 2000).

All the values obtained showed that the consumers of the medicinal plant are radiologically safe with reference to the intake of the natural radionuclides through the medicinal plant.

Conclusion: This research work has shown the safety of the use of Ocimum Gratissimum as one of very important and effective herbal plants radiologically to the consumers at Ewekoro, southwest part of Nigeria. Also, the mining of limestone activities and the production of cement in the study area does not have significant radiological health risk to the consumers of the medicinal plant, and the results obtained can serve as reference data for future studies in the study area and its environs.

\section{REFERENCES}

Ali, FA (2008). Measurements of naturally occurring radioactive materials (NORMs) in environmental samples. http://personal.ph.surrey.ac.uk/ phs $1 \mathrm{pr} / \mathrm{msc}$ dissertations/msc-diss-2008/fuad-ali-msc-dissNORM-2008.pdf

Aruna, K; Sivaramakrishina, VM (1990) Plants as protective agents against cancer. Indian Journal of Experimental Biology, 28 (11): 108-111.

Ayitey-Smith, E (1989). Prospects and Scope of Plant Medicine in Health Care. Ghana Universities Press, Accra, 1-2.

Bayhan, YK; Özbay, O (2006). Cadmium exposure from the cement dust emissions: a field study in a rural residence, Chemosphere, 63: 15461552.

Bent, S (2008). Herbal medicine in the United States: Review of efficacy, safety and regulation, J. Gen. Intern. Med. 23:854-859.

Chandrashekara, K; Somashekarappa, HM (2016). Estimation of radionuclides concentration and average annual committed effective dose due to ingestion for some selected medicinal plants of South India, Journal of Radiation Research and Applied Sciences 9: 68 - 77

Demir, TA; Isikli, B; Urer, SM; Berber, A; Akar, T; Canbek, M ; Kalyoncu, C (2005). Nickel exposure and its effects, Biometal 18: 7-13
Duffy, S; Simon, SL; Whicker, FW (1999) 137Cs Contamination of Plants Used for Traditional Medicine and Implication for Human Exposure. Journal of Environmental Radioactivity, 46: $27-$ 44. http://dx.doi.org/10.1016/S0265-931X (98)00121-0

Effraim, KD; Salami, HA; Osewa, TS (2000). The effect of aqueous leaf extract of Ocimum gratissimum on haematological and biochemical parameters in rabbits, Afr. J. Biomed.Res. 175179.

Ernst, E (1998). Harmless herbs? A review of the recent literature, Am. J. Med. 104:170-178.

Gill, LS (1992). Ethnomedical uses of plants in Nigeria. University of Benin press, Benin City, Nigeria.

ICRP (International Commission on Radiological Protection) (2007). Recommendations of the ICRP Publication, 103; Annuals ICRP, 37, 2-4.

INFOSAN (International Food Safety Authorities Network) (2011). Information on nuclear accidents and radioactive contamination of foods. Geneva: World Health Organization (WHO).

Linares, V; Bellés, M; Albina, ML; Sirvent, JJ; Sánchez, DJ; Domingo; JL (2005). Assessment of the pro-oxidant activity of uranium in kidney and testis of rats, Toxicology Letters 167: 152-161.

Lordford, T; Emmanuel, OD; Cyril, S; Alfred, AA (2013). Natural radioactivity levels of some medicinal plants commonly used in Ghana, Springer Plus. 2: 157

Mujahid, SA; Rahim, A; Hussain, S; Farooq, M (2007). Measurement of radioactivity and radon inhalation rates of different brands of cement used in Pakistan, Radiation Protection Dosimetry 130 (2): 206- 212 .

Njinga, RL; Jonah, SA; Gomina, M (2015). Preliminary investigation of naturally occurring radionuclides in some traditional medicinal plants used in Nigeria, Journal of Radiation Research and Applied Sciences 8: 208 - 215.

Odugbemi, $\mathrm{T}$ (2006). Outlines and pictures of medicinal plants from Nigeria. Akoka, YabaLagos, Nigeria: University of Lagos Press. 
Odugbemi, T; Akinsulire, O (2008). Medicinal plants species, family names and uses. In T. Odugbemi (Ed.), A textbook of medicinal plants from Akoka, Yaba-Lagos, Nigeria: University of Lagos Press. Nigeria. 541- 608.

Okoli, RI; Aigbe, O; Ohaju-Obodo, JO; Mensah, JK (2007). Medicinal herbs used for managing some common ailments among Esan People of Edo State, Nigeria, Pakistan Journal of Nutrition 6 (5): 490 - 496.

Oladipo, MOA; Njinga, RL; Baba, A; Muhammad, HL (2012). Evaluation of trace elements in some northern-Nigeria traditional medicinal plants using INAA technique, Applied Radiation and Isotopes 70: 917 -921.

Oni, OM; Isola, GA; Oni, FGO; Sowole, O (2011). Natural activity concentrations and assessment of radiological dose equivalents in medicinal plants around oil and gas facilities in Ughelli and environs, Nigeria, Canadian Center of Science and Education 1: 201 - 206.

Sowole, O (2014). Assessment of Radiological Hazard Indices from Surface Soil to Individuals from Major Markets at Sagamu Ogun State, Nigeria, Science World Journal 9 (3): 1 - 4.

Tamuno, I (2011). Traditional Medicine for HIV Infected Patients in Anti-Retroviral Therapy in a Tertiary Hospital in Kano, North West, Nigeria, Asian Pac. J. Trop. Med. 4:152-155.
Tawalbeh, AA; Samat, SB; Yasir, MS; Omar, M (2012). Radiological impact of drinks intakes of naturally occurring radionuclides on adults of central zone of Malaysia, Malaysian Journal of Analytical Sciences, 16 (2): 187 - 193.

Tettey-Labri, L; Darko, EO; Schandorf, C; Appiah, AA (2013). Natural Radioactivity Levels of Some Medicinal Plants Commonly Used in Chana. SpringerPlus, 2, 157-185.

UNSCEAR (United Nations scientific Committee on the Effects of Atomic Radiation) (2000). Sources and Effects of Ionizing Radiation. New York. United Nations.

Varier, MK (2009). Nuclear radiation detection: Measurements and analysis. New Delhi, India: Narosa Publishing House.

Vierra, RF; Simon, JE (2000). Chemical characterization of Ocimum gratissimum found in the market and used in Traditional medicine in Brazil. Journal of Economic Botany, 20: 5-6.

WHO (World Health Organization). (2002). Traditional Medicine Strategy 2002 - 2005. WHO/EDM/TRM/2002 1. Geneva. 